DOI: $10.1515 /$ hssr -2017-0012

\title{
"Flanders was empty and uncultivated and heavily wooded": Historiography as Urban Resource in the Twelfth Century
}

\author{
Jeff Rider*
}

Wesleyan University, Middletown, CT USA

\begin{abstract}
The stories that the inhabitants of a milieu tell themselves and others about that milieu are an important part of the immaterial, human, symbolic resources available to them to help them grasp, articulate and inflect their milieu's historical development and thus shape its future. The conglomerate of stories that the inhabitants of a milieu tell themselves and others about that milieu, the milieu's storyworld, is unique to that milieu and help make that milieu unique. A distinct storyworld is part of what makes one milieu different from other milieux, is 13 one of the matrices that orient and limit a milieu's future development, part of what gives it its sens and leads it to develop in certain ways and not others. This is how the storyworld of a milieu, reflected in its historiography, is a resource for the development of that milieu.
\end{abstract}

Keywords

Augustin Berque, ecumene, milieu, historiography, urban history, urbanism, Flanders, medieval cities

Writing some time not too long before 1120, Lambert of Saint-Omer begins his Genelogia [sic] comitum Flandrie (Genealogy of the Counts of Flanders) with the following statement: "Anno ab incarnatione Domini septingentesimo nonagesimo secundo, Karolo Magno regnante in Francia, Lidricus Harlebeccensis comes, uidens Flandriam uacuam et

* Romance Languages and Literatures, Wesleyan University, Middletown, CT USA, Downey House, 294 High Street, 118; jrider@wesleyan.edu 
Jeff Rider, "Flanders was empty and uncultivated and heavily wooded"...

HSS, vol. VI, no. 2(2017): 13-34

incultam ac nemorosam, occupauit eam" (Lambert: fol. 104r). ${ }^{1}$ This sentence tells us little about the actual beginnings of the county of Flanders but it does tell us something about the way Lambert imagined the beginnings of the county in the first part of the twelfth century. I cite it here because it invites us to engage in a thought experiment like that in which Rousseau engaged at the beginning of his Discours sur l'origine et les fondements de l'inégalité parmi les hommes (Discourse on the Origin and the Foundation of Inequality among Mankind), where he wrote that he would begin

par écarter tous les faits, car ils ne touchent point à la question. Il ne faut pas prendre les recherches, dans lesquelles on peut entrer sur ce sujet, pour des vérités historiques, mais seulement pour des raisonnements hypothétiques et conditionnels; plus propres à éclaircir la nature des choses, qu'à en montrer la véritable origine, et semblables à ceux que font tous les jours nos physiciens sur la formation du monde (Rousseau, 2002: Introduction, 19). ${ }^{2}$

Let me begin then by imagining the uninhabited site of a future town somewhere between the Somme and the Elbe. When the first people arrived in the area, they must have found a topography, a climate, and natural resources - water, woods, marshes, perhaps natural defenses that made the site attractive to them and led them to settle there rather than elsewhere. The first cause of a town, that is, was the presence of a set of natural resources that human beings need to survive, close enough to one another to be visited conveniently within reasonable time.

Once they had settled on a site more-or-less permanently, these initial settlers themselves became resources for one another and for new inhabitants of the site, in two ways. First, they improved the site. Some of these improvements, such as paths, were perhaps largely unplanned and unintentional, the simple result of human activity. Other improvements, such as dwellings, charcoal pits, fields, wells, canals, enclosures and so on were more deliberate. But the inhabitants were also themselves resources for one another and for new inhabitants. They were potential collaborators, they already had some knowledge of the site, they had already organized themselves socially in some way, and 
Jeff Rider, "Flanders was empty and uncultivated and heavily wooded"...

HSS, vol. VI, no. 2(2017): 13-34

they had already developed a culture specific to the site, transforming it into what one might term a milieu, which is created by the human habitation of a particular place. This milieu was a blend of the topography, climate and natural resources that first drew people to the place and the new resources - both material and immaterial - created by the transformation of the natural environment through human labor and technology and the development of a culture specific to the milieu. This notion of a milieu combining natural and human, material and immaterial resources corresponds roughly to what Augustin Berque has termed the ecumene and I would like to spend some time looking at his ideas since it helps us understand the role that historiography can play in the creation of a milieu.

Perhaps the most obvious sense of the word ecumene is the "inhabited world." Berque uses the term, however, to refer to the product or result of the relation of human beings to the biosphere. According to Berque, human beings invest the biosphere with their intentions and transform it through labor and technology. They are, moreover, shaped by their environment and at the same time they shape it. The complex material, immaterial, and historical nature of the things produced by this process results from human intentions and labor deployed in a particular natural environment and these things carry in them the traces of the milieu's past and tendencies for its future. Berque calls this interaction between human beings and the biosphere trajection, and defines it as "la conjonction dynamique, dans l'espace-temps, de transferts matériels et immatériels: des transports (par la technique), comme des métaphores (par le symbole); et c'est la convergence de tout cela vers un même foyer qui fait la réalité de la chose. Sa concrétude” (Berque, 1987: 150). ${ }^{3}$

Berque gives the example of a pencil which exists thanks to a "tissu relationnel [...] sans lequel il n'existerait pas" (Berque, 1987: 146). ${ }^{4}$ There would be no pencils without the symbolic systems of speech and writing and the existence and interrelations of beings who communicate through these systems. A pencil also requires forests, logging, the manufacturing of crystalized carbon, paper mills, and writing surfaces (Berque, 1987: 146-47). A pencil is thus the product of "la chaine de transferts matériels par laquelle un bout de sapin scandinave s'est finalement retrouvé crayon sur mon bureau" and is destined to "finir un jour dans la corbeille, puis 
Jeff Rider, "Flanders was empty and uncultivated and heavily wooded"...

HSS, vol. VI, no. 2(2017): 13-34

dans l'atmosphère via l'incinérateur public, et de là un peu partout sur la terre et au fond des mers," but only after it has "écrit beaucoup de choses, qui en principe relèveront de la noosphère mais n'en existeront pas moins matériellement sur du papier, ainsi que biologiquement dans les neurons des gens qui les auront lues" (Berque, 1987: 149). ${ }^{5}$

Through trajection, writes Berque, we have established "par la geste et la parole, un commerce qui les [the things of our milieu] a investies de notre humanité" (Berque, 1987: 157). " "[L]a trajection de l'humain dans son environnement," he continues, "[est] ce qui fait justement de celui-ci un milieu bumain" (Berque, 1987: 170). ${ }^{7}$ The trajective nature or trajectivity of our environment "nous donne bel et bien prise sur [sa] dimension physique" and these "prises trajectives" are what

permettent aux diverses sociétés de comprendre et d'utiliser la réalité des choses. Dans la concrétude et la singularité de leur histoire, ces prises se configurent en motifs, lesquels, agrégés en contrées, permettent de qualifier et d'identifier régions ou pays [...]. Ces motifs écouménaux sont spatiotemporels [...]. Ce sont à la fois, dans l'espace, des configurations, et, dans le temps, des motivations. Autrement dit, les motifs de l'écoumène sont à la fois ce que nous y voyons (des forêts, des villes, des montagnes, ...) et quelque chose qui suscite en nous des raisons d'agir de telle ou telle façon.

De ce point de vue, les motifs écouménaux sont en même temps des empreintes et des matrices. Empreintes parce qu'ils portent la marque de l'existence humaine, que ce soit matériellement (par exemple ces aménagements que sont la Muraille de Chine ou le bocage vendéen) ou immatériellement (par exemple la manière aborigène ou la manière aussie de percevoir, fort différemment, le même environnement), mais le plus souvent les deux à la fois [...]. De manière générale, les motifs écouménaux portent l'empreinte des systèmes techniques de l'humanité; ils sont l'incarnation visible de notre [trajection of our environment]. Mais en même temps, ils en sont la part symbolique, celle que nous ne voyons pas mais qui, rapatriant le monde en nous-mêmes, émeut notre corps animal par le truchement des signes. En ce sens, les motifs écouménaux sont des matrices de notre sensibilité, ainsi que, à travers elle, de notre comportement (Berque, 1987: 240-42). ${ }^{8}$

Ecumenal motifs are spatio-temporal collections of particular grips/holds (prises) on the concrete physical features of a particular 
Jeff Rider, "Flanders was empty and uncultivated and heavily wooded"...

HSS, vol. VI, no. 2(2017): 13-34

milieu, of approaches to and transformations of that milieu. These approaches and transformations are always unique, because they are always contingent. Contingency, for Berque, is neither chance nor necessity. Ecumenal motifs are the result of "un contact effectif, [...] existential" between a particular set of human beings, with their history, and a particular place, with its history (Berque, 1987: 330; cf. 333, 33738). ${ }^{9} \quad$ A particular milieu is thus different from every other milieu because it is a place where two or more histories come together. These histories and the contact between them are not due to chance - a place's topography is not due to chance, nor is the arrival there of a group of people - but the contact between them is not necessary and inevitable either. It is because the place was the way it was and because the people arrived there, each for their own reasons, as a result of their own histories, and because of the subsequent trajection of that place by those people that a unique milieu is created whose ecumenal motifs characterize it and allow its identification as a place in which a particular set of humans have invested a particular part of the biosphere with their particular intentions and transformed it in a particular way with their particular labor and technologies over a period of time. These motifs are the material traces, the residue, of the history of a milieu's habitation.

These ecumenal motifs are also, however, matrices for future actions and intentions, for future investments in the milieu and transformations of it. The "effective, [...] existential contact" between a particular set of human beings, with their history, and a particular place, with its history, creates a "logique trajective, [qui,] comme font les gyroscopes, tend à se maintenir elle-même" (Berque, 1987: 330). ${ }^{10}$ Elsewhere, he refers to this "trajective logic" as a sens, by which he means a direction, a tendency, an orientation and meaning all at once. "Un certain sens," he writes, "mariant technique, symbole et climat, travaille l'ensemble de la relation d'une société à son environnement, et la fait se déployer en vertu de ce sens" (Berque, 1987: 185). ${ }^{11}$ This sens explains why a milieu evolves "dans un sens plutôt que dans un autre," why it goes "quelque part, au lieu de nulle part" (Berque, 1987: 186). ${ }^{12}$ A milieu's sens is what makes it idiosyncratic (Berque, 1987: 205).

Ecumenal motifs serve as matrices for future actions and intentions in two ways. They do so, first, simply because they exist materially. A 
Jeff Rider, "Flanders was empty and uncultivated and heavily wooded"...

HSS, vol. VI, no. 2(2017): 13-34

milieu's terrain, climate, existing structures, and infrastructure must all be taken into account when future transformations of the milieu are planned or made. But ecumenal motifs also mold future actions and intentions through what Berque calls symbolism. This is the second aspect of the relation that Berque postulates between human beings and the biosphere. "Le symbole," he writes, "joue [...] en sens inverse de la technique. Celle-ci est bel est [sic] bien une extériorisation, qui prolonge notre corporéité hors de notre corps jusqu'au bout du monde; mais le symbole est au contraire une intériorisation, qui rapatrie le monde au sein de notre corps" (Berque, 1987: 207).13 "La fonction symbolique [...] consiste donc à rendre présentes au dedans de mon corps des choses qui en sont physiquement éloignées. Cela, ce n'est pas une projection ; c'est, tout au contraire, une introjection" (Berque, 1987: 208). ${ }^{14}$

This interiorization or introjection of the external world through symbolism is possible, according to Berque, because we have invested the external world with our motivations and technology.

La trajection, c'est ce double processus de projection technique et d'introjection symbolique. C'est le va-et-vient, la pulsation existentielle qui [...] fait que le monde nous importe. Il nous importe charnellement, parce qu'il est issu de notre chair sous forme de techniques et qu'il y revient sous forme de symboles. C'est en cela que nous sommes humains, en cela qu'existe l'écoumène, et c'est pour cela que le monde fait sens (Berque, 1987: 208). ${ }^{15}$

"Le monde fait sens," he writes,

et les choses nous émeuvent parce que nous les existons: notre être y est trajecté, les intégrant avec notre chair dans une même structure ontologique. Cette trajectivité (la pulsation existentielle "projection technique: introjection symbolique" de notre corporéité-mondanité) fait que les choses peuvent nous toucher intimement; et c'est fondamentalement cela qui donne sens aux signes qui les représentent. [...] Ce qu'on appelle le référent du signe ne peut être tel (et le signe n'a donc de sens) qu'en ce que la chose représentée par le signe est instituée ontologiquement par trajection de l'être humain dans ladite chose. Celle-ci n'est pas un en-soi, et ce n'est pas un tel en-soi que représente le signe; c'est la trajectivité de la chose, c'est-à-dire ce 
Jeff Rider, "Flanders was empty and uncultivated and heavily wooded"...

HSS, vol. VI, no. 2(2017): 13-34

en quoi elle participe de l'être de l'humain. Ce n'est qu'à cette condition que le sens véhiculé par le signe signifie, c'est-à-dire émeut le corps animal du locuteur. Il l'émeut par sympathie (i.e. par sentir-ensemble), dans la mesure, et uniquement dans la mesure, où il y rapatrie [human trajection of the environment] (Berque, 1987: 216, 218). ${ }^{16}$

According to Berque, then, we incorporate the trajected milieu through symbolism, bringing into ourselves not only the things in our milieu but also, with them and through them, the material and immaterial traces they bear of the milieu's past and its sens, the disposition or tendencies created by the existing milieu. This is how the introjection of the milieu through symbolism becomes a matrix of "our sensitivity as well as, through it, our behavior" (my emphasis), "arouses in us reasons to act in this or that fashion," and shapes our thinking about the milieu, our relation to it, and our future actions with respect to it. It is in this way that, Berque writes, "à chaque instant c'est une histoire que chaque chose incarne, et ce sont des lendemains qu'elle engage" (Berque, 1987: 149-50). ${ }^{17}$

Berque recognizes that this internal representation of our milieu created through symbolism is not simply a reflection of the external world and is subject to modification and elaboration - it is indeed this imaginative manipulation that allows us to make plans and do new things in our milieu - but he also believes that this imaginative manipulation is not utterly free precisely because it is applied to a pre-existing milieu with its idiosyncratic sens. "Ce qu'apporte la symbolicité," he writes, "c'est la faculté d'une élaboration incommensurablement plus libre du sens; mais elle ne le crée pas. Elle le tient, par le fil d'Ariane de l'histoire et par le corps animal de chacun d'entre nous, originellement et originairement, de l'insondable obscurité du commencement de l'univers" (Berque, 1987: 209). ${ }^{18}$

Berque's analysis of the ecumene, which creates unique milieux with particular sens through the back and forth of technological projection and symbolic introjection, helps me, at least, think about the nature of stories about a milieu and the role they play in creating it. Imagining, and then recounting, stories about a milieu - which are meaningful because the milieu has been trajected with human being - is one aspect of incorporating, introjecting, that milieu, grasping its unique sens, and imagining its tomorrows. Telling stories about a milieu is a way of 
Jeff Rider, "Flanders was empty and uncultivated and heavily wooded"...

HSS, vol. VI, no. 2(2017): 13-34

articulating, grasping and inflecting its sens. Stories help us think about a milieu and transform it. As Berque puts it, they "nouriss[ent] notre [trajection of our environment] donnant plus de sens au monde" (Berque, 1987: 277). ${ }^{19}$ They are one of the ways the inhabitants of a milieu are resources for one another, transform their milieu and endow it with a unique sens.

Urban milieux are trajected by human being in a particularly dense, dynamic and complex way and these milieux are particularly rich in material and human resources. The stories the inhabitants of an urban milieu tell themselves and others about their milieu likewise form a particularly dense, dynamic, complex, and rich conglomerate - a significant immaterial, symbolic resource that can be greater than the milieu's material resources. In the Middle Ages, moreover, towns were not usually self-sufficient and depended on neighboring communities for food and raw materials, while rural landowners could often be found living in towns. People came and went between towns and smaller communities in the neighboring countryside and transported their stories with them. The medieval urban milieu and its material and immaterial resources, including stories about that milieu, thus extended beyond jurisdictions and natural and artificial boundaries. A medieval urban milieu's storyworld did not stop at town walls and jurisdictions either but extended beyond what one might think of as a town legally or physically defined.

The first clause of the customs of the Merchant Guild of Saint-Omer, which can be dated to the period between 1083 and 1127, reads as follows: "Si quis mercator manens in villa nostra vel in suburbio in gildam nostram intrare noluerit et pergens alicubi deturbatus fuerit vel res suas amiserit vel ad duellum fuerit provocatus, omnino nostro carebit auxilio" (Espinas and Pirenne, 1901: 192). ${ }^{20}$ This suggests that merchants living outside the town limits could be members of the guild, and this idea perhaps finds support in the fifth clause of the charter William Clito gave Saint-Omer in 1127 where the count states that: "Omnes qui gildam eorum habent, et ad illum pertinent, et infra cingulam ville sue manent, liberos omnes a teloneo facio ad portum Dichesmude et Graveningis" (Espinas, 1947: 46). ${ }^{21}$ There seems to be a distinction here between members of the guild who live inside the town limits and those 
Jeff Rider, "Flanders was empty and uncultivated and heavily wooded"...

HSS, vol. VI, no. 2(2017): 13-34

who live outside them. This again suggests that membership in the guild was not limited to men living inside the town. If this was the case, if guild membership was open to merchants from the neighborhoods around the town, then the guild's storyworld must have extended beyond the town limits as well.

We find similar examples of the social and cultural porousness of a town in Galbert of Bruges's description of the deliberations surrounding the election of a new count of Flanders after the assassination of Count Charles of Flanders in 1127. Galbert writes that on March 27, after the Flemish barons had left the siege of the count's assassins in Bruges in response to a summons by King Louis VI to come to him in Arras in order to choose a new count, "convenerunt burgenses nostri in agrum quod suburbio adjacet intra septa villae, convocatis undecumque Flandrensibus circa nos, conjuraverunt simul super sanctorum reliquias" to elect a new count who would work for the common welfare. "Eratque multitudo maxima conjurantium in id ipsum," Galbert relates, and he mentions by name nine villages around Bruges from which the coswearers came (Lapscheure, Oostkerke, Uitkerke, Lissewege, Slijpe, Gistel, Oudenburg, Lichtervelde, and Jabbeke) (Galbert of Bruges, 1994: [51].2-6, p. 100). ${ }^{22}$ Three days later, after the barons had returned and told the townspeople that they had chosen William Clito to be the new count, Galbert writes that

cives procrastinaverunt responsum de receptione seu electione novi consulis concedenda sibi ut, accitis Flandrensibus cum quibus eligendi sacramenta constituerant, simul aut concessionem facerent aut legationis regiae litteras refutarent. Et $[\ldots]$ ex communi consilio mandantes pro Flandrensibus tota illa nocte ut electionem in persona novi consulis factam concederent aut reprobarent (Galbert, 1994: [52].48-55, p. 102).23

The next day, he continues, "postquam convenerant cives cum Flandrigenis, ex communi consilio consenserunt ut" they would send a delegation made up of "viginti milites et duodecim e civibus seniores et prudentiores" to meet with the men of Ghent and the king's messengers to discuss the election (Galbert, 1994: [53].1-4, p. 102). ${ }^{24}$ The people of Bruges - whom, it should be noted, included both knights and burghers 
Jeff Rider, "Flanders was empty and uncultivated and heavily wooded"...

HSS, vol. VI, no. 2(2017): 13-34

- clearly felt that there was a difference between them and the people living in these nearby villages but they also felt that they had common interests with them. The people in these villages thus both belonged and did not belong to the milieu of Bruges, but they undoubtedly brought their stories with them when they came to town - and took the stories they heard there home with them when they left - and these stories were, I think, part of Bruges's storyworld in the early twelfth century just as were the stories of the knights, burghers and clergy living in the town.

Writing his biography of Count Charles in the same year, Walter of Therrouanne relates the following story about the fate of one of the participants in the conspiracy to murder the count:

Ille [Ysaac] uero, diurnis ubi audebat latitans et nocturnis horis qua poterat fugitans, ad domum sororis suę, quam prefatus Guido de Stenfordo uxorem habebat, deuenit, et eius conductu usque ad monasterium sancti Iohannis Teruanensis in monte nostrę ciuitati imminente constitutum profugit. Nam quia monachus fieri, diuino uel humano coactus timore, uolebat, monachum quendam Heiamensem, qui ipsum ei habitum donaret, ibidem operiri proposuerat.

\section{[36.] De divulgatione eius, et monachatu, captione, et interitu}

Fama namque uolante delatum et per totam urbem confestim est diuulgatum quod in monasterio sancti Iohannis laterent qui patrem patrię Karolum occidissent. Arnulfus ergo, filius Eustachii aduocati, uolens et ipse sanguinem comitis uindicare, in cuius ultionem iam orbem ipsum audiebat conspirare, nocte imminente, apparitores suos eo dirigit, qui abbaciam tota nocte custodiant, ne qui latebant in tenebris effugere usquam ualeant. Isaac autem ubi insidias sibi esse paratas cognouit, ad domnum abbatem Folquinum tremebundus confugit, et, ut optatum sibi monachi habitum ipse iam concederet, humili supplicatione et importuna satis tandem obtinuit. Verumtamen Arnulfus sequenti die cum suis monasterium adiit, et illum, eductum et ex ipsius confessione deprehensum, continuo ueste monachili expoliari et, nudum ac discalciatum, reuinctis post tergum manibus, ad ciuitatem cum tumultu pertrahi precepit" (Walter, 2006: [35].19-[36].19, p. $59-60) \cdot{ }^{25}$

One's first impression is that Walter thought that the abbey of Saint John was not part of the town of Thérouanne since he describes it as "situated on the hill overlooking the city." The distance between the 
Jeff Rider, "Flanders was empty and uncultivated and heavily wooded"...

HSS, vol. VI, no. 2(2017): 13-34

town and the abbey was not great, however, and was quickly and easily traversed by flying rumor, and the son of the advocate of Therouanne clearly felt that the abbey was within his sphere of authority and he brought his captive into the town for justice. So was the abbey of Saint John part of the town of Thérouane or not? Different people would probably give different answers based on different criteria. It may well be that the monks of Saint John's abbey and people living around it felt that they lived in Thérouanne, even if someone like Walter, living in the town's center did not, just as people from Bronxville, New York, may well tell you that they live in New York, even if people living around Central Park would not consider Bronxville to be part of the city. The fact that rumor flew quickly back and forth between the abbey and the town suggests to me that stories did as well and that the abbey and people living around it contributed to the town's storyworld.

Even stories that are composed clearly outside an urban milieu can become part of the conglomerate of stories that that milieu's inhabitants tell themselves and others about their milieu. Guibert of Nogent, for example, wrote some very well-known passages about the town of Laon and while it is impossible to know whether Guibert and his fellow monks felt they belonged to the milieu of Laon, it seems unlikely to me (Guibert, 1996). It seems more likely to me that when Guibert wrote those passages about Laon, he felt that he was writing about another milieu and not about a milieu to which he belonged. I would not myself, therefore, include those passages in the corpus of urban historiography of Laon. There is, unfortunately, no evidence of which I am aware that Guibert's autobiography was read and known within Laon but since, like Rousseau, I have laid facts aside, let us imagine that the passages concerning Laon had been copied into a register of some sort in that town. This would indicate that at least one inhabitant of the town had appropriated those passages for himself and that Guibert's story about Laon had entered into the conglomerate of stories that the inhabitants of Laon told themselves and others about their town. My point is that stories can enter the inhabitant's conglomerate of stories about their milieu even if they were not composed in that milieu and even if their author did not consider himself part of it.

Some scholars might tend to deny Guibert of Nogent the title of 
Jeff Rider, "Flanders was empty and uncultivated and heavily wooded"...

HSS, vol. VI, no. 2(2017): 13-34

urban historiographer not only because of his distance from Laon but because of his monastic status. They might be willing to award this title to secular clergy like Galbert or Walter, who lived in the town about which they write, but it is not uncommon to distinguish monastic historiography from urban historiography even when the monastery in question lies within or next to a town. I would suggest, however, that it is an author's sense of belonging to an urban milieu that makes his or her work urban historiography rather than his or her institutional or group origin, and it is clear that monks sometimes did feel that they belonged to an urban milieu.

The Genealogia Flandrensium comitum (Genealogy of the Flemish Counts), which is better known as the Flandria Generosa (or the A version of the Flandria Generosa or the Flandria Generosa $A$ to distinguish it from later versions), was finished in the Abbey of SaintBertin on the edge of Saint-Omer shortly after 1164. The oldest manuscript containing the work comes from the library of Saint-Bertin and is probably the author's manuscript. It is at least the manuscript from which all other existing copies descend. Since the work was composed by a monk and is a genealogical history of the counts of Flanders from 792 to 1164, some scholars, I expect, would be reluctant to include it in the corpus of historiography from Saint-Omer.

The Bertinian compiler or copyist adds, however, a long passage about the battle of Cassel in 1071 that was not in any of his sources, and he goes on to explain how, after the king of France was defeated by Count Robert I at the battle, he withdrew to Saint-Omer, which had supported Robert, burned the suburb around the town and entered the town, where his men sent its citizens fleeing, despoiled its churches, injured monks, tormented clergy, and molested both married women and girls. The passage then goes on to tell us how, in exchange for a gift of land from Robert, the bishop of Paris got the king to flee the city by night by telling him that Robert and the count of Boulogne were nearby with a huge army and on the verge of capturing him. The compiler or copyist never refers to Saint-Omer as "our town" or anything like this, but his description of its sack is, as far as I know, unique among eleventh- and twelfth-century historians and suggests a unique interest in it.

When the compiler or copyist reread this passage, moreover, he seems to have felt that he needed to round off the story of the king's 
Jeff Rider, "Flanders was empty and uncultivated and heavily wooded"...

HSS, vol. VI, no. 2(2017): 13-34

destructive sojourn in Saint-Omer in some way and wrote in the margin: "rege itaque fugiente, comes in crastinum adueniens urbem recepit, sed de iniuriis ecclesiarum et populi uehementer condoluit" (Saint-Omer: fol. 67r2). ${ }^{26}$ This marginal addition is interesting for two reasons. First, it again suggests that the monastic compiler or copyist felt a particular attachment to the town of Saint-Omer, not just to the monastery of Saint-Bertin, but to the whole town. Second, it shows us how stories about an urban milieu could shape the future of that milieu. By suggesting that the count was concerned for the people of Saint-Omer and commiserated with them, it creates the sense of a particular bond between the town's inhabitants and the count. To the degree that this sense of a special bond between the inhabitants of Saint-Omer and the count became a part of the storyworld of Saint-Omer, it would have disposed the inhabitants in certain ways toward the count and toward other powers like the king of France. It would thus have affected future relations between the inhabitants, the count, and other powers and have helped create the particular sens of the milieu of Saint-Omer.

Anyone can tell a story about his or her milieu and this activity has always been - even now - primarily mental, told only within our minds, and, secondarily, oral, told to other people. Written stories about a milieu - historiography - are thus a small part of this much larger storytelling about the milieu, but they are also the only part of that storytelling that survives for most of the human past. This puts us in an odd position. If we want to understand how the stories told about a past milieu helped the inhabitants of that milieu grasp, articulate and inflect its sens, how these stories served as matrices for the inhabitants' future actions and intentions, we have to imagine the large conglomerate of predominantly mental and oral stories they told themselves and others about their milieu by means of a very small part of those stories. Written stories, moreover, are more subject to socio-economic influences than mental and oral storytelling because writing always requires a certain socioeconomic status that gives one access to the things one needs to write including an education - and increases the chances that what one writes will survive. We thus have to imagine the large conglomerate of predominantly mental and oral stories a milieu's inhabitants told themselves and others about their milieu not only by means of a very 
Jeff Rider, "Flanders was empty and uncultivated and heavily wooded"...

HSS, vol. VI, no. 2(2017): 13-34

small set of those stories but by a very small set of those stories told by a very small set of the inhabitants, one that, for example, rarely included women and children. The written stories of a milieu, in other words, are never representative of the full set of stories the inhabitants of a milieu told themselves and others about their milieu.

Written stories are also an especially formal kind of storytelling that are more subject to generic influences than mental or oral storytelling. These generic influences tend to efface the particularities of both the author and the subject of his or her story and make it even more difficult to imagine the conglomerate of predominantly mental and oral stories a milieu's inhabitants told themselves and others about their milieu. Describing a medieval town with generic models inherited from classical antiquity, for example, may have led writers and their audiences to grasp, articulate and inflect their milieu's sens in new ways, just as writing fixed form verse often lead poets to discoveries they would not have made if they were writing in free verse, but the discoveries about a medieval town's sens that were made thanks to the use of classical models are unlikely to have been widely shared or understood and thus not typical of the large cloud of storytelling hovering over the town. It is of course possible to focus on the generic aspects of historiography and this is to some degree necessary in order to try to distinguish generic from nongeneric features of a story, but the generic features of written stories about a milieu - or, in other words, the similarities between written stories about a milieu or a set of milieux - have less to tell us about a milieu's unique conglomerate of predominantly mental and oral stories than do the non-generic ones.

In the twelfth century, certain histories written in Latin do seem to offer us a limited and probably somewhat distorted access to the conglomerate of oral stories a milieu's inhabitants told themselves and others about their milieu, but these are precisely the least generic and the most idiosyncratic moments of the texts. Galbert of Bruges's journalistic history of the assassination of Count Charles of Flanders in 1127 and the ensuing civil war, for example, is one of the least generically traditional works of the high Middle Ages and here and there it gives us insight into what popular stories of the time may have been like. An outstanding example of this is the tale of Erembald and Dedda, which Galbert added 
Jeff Rider, "Flanders was empty and uncultivated and heavily wooded"...

HSS, vol. VI, no. 2(2017): 13-34

to his history when he revised it in order to discredit the family that had led the conspiracy against Count Charles and explain their unusual execution by being thrown from a tower of the count's house in Bruges. Galbert tells us that the founder of this family's fortunes, the knight Erembald, was the vassal and confidant of Boldran, the castellan of Bruges. Their relation did not prevent Erembald from entering into an adulterous liaison with Boldran's wife, Dedda, however, and, as a result, Erembald "domino suo semper machinabatur mortem." His chance came when the men of Bruges set out by ship on a military expedition. "Cum vero navibus prolaberent Scaldim fluvium," writes Galbert,

Boldrannus castellanus et Erembaldus miles suus, cui prae ceteris confidebat, ceterique plures omnes loricas induti et ad pugnam praeparati, venit nox et fixerant anchoram in medio amne ut diem expectarent. [...] Facto quoque noctis silentio, dum castellanus ad mingendum in ora stetisset navis, ille Erembaldus retro accurrens, longe a navi projectum dominum in profundum torrentis aquosi praecipitavit. Hoc vero dormientibus ceteris factum est et nemo praeter adulterum illum sciebat quo devenisset castellanus ille (Galbert of Bruges, De multro [71].8-20, p. 125).27

Erembald then returned to Bruges, married Dedda, became castellan himself, and fathered the conspirators in Charles's murder, who were later punished for his sins as well as their own.

This murder, if it happened, would have occurred about sixty years before Galbert was writing and is the oldest event he relates in his chronicle. It is evident, moreover, that the only person who would have known what had happened to Boldran was Erembald and he had no interest in telling anyone. The story Galbert tells, that is, must have been invented to explain what had happened after Boldran had disappeared on an expedition and his vassal Erembald had returned without him and married his widow Dedda. Since these events occurred long before Galbert was writing, it seems likely that he is repeating a story he has heard rather than inventing one himself. Some of the details, moreover such as adultery with a friend's wife; the passionate relation between Erembald and Dedda that continued after they were married since she bore at least five children; and the detail that Boldran was urinating when he was pushed into the river in the dead of night - could be found in 
Jeff Rider, "Flanders was empty and uncultivated and heavily wooded"...

HSS, vol. VI, no. 2(2017): 13-34

popular stories even now. The story Galbert relates has the air of having been rolled around by many tongues and worn down to a hard core by popular narrative traditions. It was not an accurate report of what had happened, but it was an accurate report of the way the people of Bruges thought things happened and tells us something about the narrative models and character-types they used in their stories about the past.

It is thus fascinating that the earliest surviving evidence of the existence of Galbert's chronicle is a brief French résumé of Galbert's account of the servile and adulterous origins of the Erembalds, which Roland or Antoine de Baenst, members of a prominent bourgeois family of Flanders, copied into a family record book at the end of the fifteenth century. It is especially noteworthy that the part of the chronicle that one of the members of this bourgeois family deemed worth copying was this late-eleventh or early-twelfth-century popular story. He must have thought it was a good story worth remembering and repeating.

I draw three general conclusions from the proceeding reflections. First, the stories that the inhabitants of a milieu tell themselves and others about that milieu are an important part of the immaterial, human, symbolic resources available to them to help them grasp, articulate and inflect their milieu's sens and thus shape its future.

Second, the conglomerate of stories that the inhabitants of a milieu tell themselves and others about that milieu, the milieu's storyworld, is unique to that milieu and help make that milieu unique. A distinct storyworld is part of what makes one milieu different from other milieux, is one of the matrices that orient and limit a milieu's future development, part of what gives it its sens and leads it to develop in certain ways and not others. This is how the storyworld of a milieu, reflected in its historiography, which is a small part of that storyworld, is a resource for the development of that milieu.

A milieu's storyworld is never, however, harmonious or homogenous. We should not imagine it to be a common set of stories shared among all the inhabitants of a milieu. Different groups, and ultimately each person, will know a different set of stories about the milieu they inhabit and will prefer some of those stories to others. Because individuals each have a unique set of stories, a unique storyworld, about the milieu they inhabit, they will each grasp, articulate and inflect the milieu's sens in a unique way 
Jeff Rider, "Flanders was empty and uncultivated and heavily wooded"...

HSS, vol. VI, no. 2(2017): 13-34

and they will each have a unique set of matrices for thinking about the milieu's evolution. The collective storyworld of a milieu, that is, is a heterogeneous conglomerate of competing as well as complementary stories and subsets of stories, and conflicts between groups in a milieu can be viewed as a struggle to impose one or another set of stories as the dominant set in that milieu. This is not a purely ideological struggle insofar as telling stories about the milieu one inhabits is perhaps the most important means of symbolically incorporating, introjecting, both the material and the immaterial components of that milieu "into the heart of our body" as Berque puts it. The milieu "is significant for us carnally because it issued from our flesh in the form of technologies and returns to our flesh in the form of symbols," especially stories. Stories thus bring into our bodies both the things in our milieu and, with them and through them, the material and immaterial traces they bear of the milieu's past and its sens, the disposition or tendencies created by the existing milieu, and give us a hold on its future. This is why the storyworld is a field of such conflict and contestation.

If, finally, one's goal is to study the storyworld of a particular milieu at a particular time and understand how that storyworld served as a resource for the milieu's inhabitants and inflected the milieu's sens, one needs to cast one's net as widely as possible and include in one's study every story and every hint of a story one can find that the inhabitants might have told themselves and others about the milieu, regardless of its source, length, or genre. These stories or hints of stories may have been composed by burghers, clergy, monks, town officials, or aristocrats. They may be a sentence long, a paragraph long, or form a major part or all of a work. We may find them in urban chronicles, but also in world chronicles, monastic chronicles, saints' lives, genealogies, almanacs, diaries, charters, account books, and so on. Visual materials should also be taken into account insofar as they provide clues about a milieu's storyworld. All these sources can give us insight, even if it is only a glimpse, into a milieu's storyworld. A storyworld is not primarily a written or visual phenomenon and although we usually have access to it only through written or visual works, we should not let the conventions and socio-economic limitations of writing and visual representation deprive us of resources we can put to good use. 
Jeff Rider, "Flanders was empty and uncultivated and heavily wooded"...

HSS, vol. VI, no. 2(2017): 13-34

\section{References}

Berque, A. Ecoumène: Introduction à l'étude des milieux humains. Paris: Belin, 1987.

Espinas, G. "Le privilège de Saint-Omer de 1127." Revue du Nord 29 (1947): 4348.

Espinas, G., and H. Pirenne. "Les coutumes de la gilde marchande de SaintOmer." Le Moyen Age: Revue d'bistoire et de philologie 5 (1901): 190-94.

Galbert of Bruges. De multro, traditione et occisione gloriosi Karoli comitis Flandriarum.

Ed. J. Rider. Corpus Christianorum, Continuatio Medieualis, 131. Turnhout, Belgium: Brepols, 1994.

Galbert of Bruges. The Murder, Betrayal, and Slanghter of the Glorious Charles, Count of Flanders. Trans. J. Rider. New Haven: Yale University Press, 2013.

Guibert of Nogent. A Monk's Confession: The Memoirs of Guibert of Nogent. Trans. P.

Archambault. University Park, Pa.: Pennsylvania State University Press, 1996.

Lambert of Saint-Omer. Genelogia [sic] comitum Flandrie. Ghent, Universiteitsbibliotheek Gent, BHSL.HS.92, fols. 104r-105r', adore.ugent.be/OpenURL/app?id=archive.ugent.be:018970A2-B1E8-11DFA2E0-A70579F64438\&type $=$ carousel (images 113, 112, in that order). Accessed 29 May 2017.

Rider, J. "Composing a Historical Compilation in the Twelfth Century: The Author's Manuscript of the Genealogia Flandrensium comitum (or Flandria Generosa) from Saint-Bertin." Peregrinations: Journal of Medieval Art \& Architecture 4.4 ([2015 for] 2014): 1-29, digital.kenyon.edu/perejournal/vol4/iss4/2. Accessed 29 May 2017.

Rousseau, J.-J. Discours sur l'origine et les fondements de l'inégalité parmi les hommes. Université du Québec à Chicoutimi, 30 March 2002, classiques.uqac.ca/ classiques/Rousseau_jj/discours_origine_inegalite/origine_inegalite.html.

Accessed 29 May 2017.

Saint-Omer, Bibliothèque d'Agglomération de Saint-Omer, MS 746, fols. 64r-68v. Walter of Thérouanne. Vita Karoli comitis Flandrie. In Walteri arcbidiaconi Teruanensis "Vita Karoli comitis Flandrie"et "Vita domni Ioannis Morinensis episcopi" quibus subiunguntur poemata aliqua de morte comitis Karoli conscripta et quaestio de eadem facta. Ed. J. Rider. Corpus Christianorum, Continuatio Medieualis, 217. Turnhout, Belgium: Brepols, 2006. 27-79.

1 "In the $792^{\text {nd }}$ year after the Lord's incarnation, when Charlemagne was reigning in France, seeing that Flanders was empty and uncultivated and heavily wooded, Count Lidric of Harelbeke took possession of it." All translations are mine unless otherwise noted. 
Jeff Rider, "Flanders was empty and uncultivated and heavily wooded"...

HSS, vol. VI, no. 2(2017): 13-34

2 "By putting aside all the facts because they are of no concern whatsoever with respect to this question. The investigations one can undertake on this subject must not be taken for historical truths but simply as hypothetical and conditional arguments better suited to elucidate the nature of things than to show their true origin, like those our physicists make every day about the formation of the world."

3 "The dynamic conjunction, in space and time, of material and immaterial transfers: both transportations (through technology) and metaphors (through symbols): and it is the convergence of all this in a single center that constitutes the reality of a thing. Its concreteness."

4 "Web of relations [...] without which it would not exist."

5 "A chain of material transfers through which a piece of Scandinavian pine finally turned up as a pencil on my desk"; "end up one day in a trash can, and then in the atmosphere thanks to the public incinerator, and from there a little bit everywhere on the earth and at the bottom of the seas"; "written many things that belong in principle to the sphere of human thought but that also exist materially on paper as well as biologically in the neurons of the people who have read them."

6 "By actions and words, a commerce that has invested [the things of our milieu] with our humanity."

7 "The trajection of the human in his or her environment ... [is] precisely what makes it a buman milieu."

8 "Lets us get a solid grip/hold on [its] physical dimension"; "trajective grips/holds"; "permit diverse societies to understand and to utilize the reality of things. In the concreteness and singularity of their history, these grips/holds form themselves into motifs, which, aggregated into lands, allow us to qualify and identify regions or countries [...]. These ecumenal motifs are spatio-temporal [...]. They are both configurations in space and motivations in time. In other words, the motifs of the ecumene are simultaneously what we see (forests, towns, mountains ...) and something that arouses in us reasons to act in this or that fashion. From this point of view, ecumenal motifs are simultaneously traces and matrices. Traces because they bear the mark of human existence, either materially (for example, improvements like the Great Wall of China or the countryside of the Vendée) or immaterially (for example, the very different ways in which Aborigines and Australians perceive the same environment), but usually both at the same time [...]. Generally, ecumenal motifs bear the traces of humanity's technological systems; they are the visible incarnation of our [trajection of our environment]. But at the same time, they are the symbolic part [of that trajection], the part we don't see but which, repatriating the world into ourselves, affects our animal body 
Jeff Rider, "Flanders was empty and uncultivated and heavily wooded"...

HSS, vol. VI, no. 2(2017): 13-34

by means of signs. In this way, ecumenal motifs are matrices of our sensitivity as well as, through it, our behavior."

9 "An effective, [...] existential contact."

10 "Trajective logic [that,] like a gyroscope, tends to maintain itself."

11 "A certain sens bringing together technology, symbolism and climate, shapes the whole of a society's relation to its environment and leads it to unfold in virtue of this sens."

12 "In one sens rather than another"; "somewhere rather than nowhere."

13 "Symbols play a role [...] which is the opposite of that of technology. This latter is indeed an exteriorization that extends our bodiliness beyond our body as far as the end of the world; but symbols are on the contrary an interiorization that repatriates the world into the heart of our body."

14 "The symbolic function [...] thus consists of making present inside my body things that are physically distant from it. This is not a projection; it is, on the contrary, an introjection."

15 "Trajection is this double process of technological projection and symbolic introjection. It is the back and forth, the existential pulsation which [...] makes the world significant for us. It is significant for us carnally because it issued from our flesh in the form of technologies and returns to our flesh in the form of symbols. It is in this back and forth that we are humans, in it that the ecumene exists, and thanks to it that the world makes sense."

16 "The world makes sense and things move us because we exist them: our being is trajected through them, integrating them into our flesh in a single ontological structure. This trajectivity (the existential pulsation of our bodiliness and worldliness through 'technological projection: symbolic introjection') creates a situation in which things can touch us intimately; and that is fundamentally what gives meaning/direction to the signs representing them. [...] What we call the referent of a sign can be a referent (and the sign thus makes sens) only insofar as the thing represented by the sign has been instituted ontologically by the trajection of human being into the aforesaid thing. This thing does not exist in-and-of-itself, and the sign does not represent something that exists inand-of-itself; it represents the thing's trajectivity, which is to say that by which it participates in human being. It is only on this condition that the sens carried by the sign signifies, which is to say moves the animal body of the speaker. It moves it by sympathy (i.e. by feeling-together), to the degree and uniquely to the degree that the sign repatriates the [human trajection of the environment] into the animal body."

17 "At each moment, each thing incarnates a history and engages tomorrows." 
Jeff Rider, "Flanders was empty and uncultivated and heavily wooded"...

HSS, vol. VI, no. 2(2017): 13-34

18 "Symbolicity brings with it the possibility of an immeasurably freer elaboration of sens; but it does not create it. It holds onto it, originally and originarily, by the Ariadne's thread of history and by the animal body of each of us stretching back to the unfathomable obscurity of the beginning of the universe."

19 "Nourish our [trajection of our environment] giving more sens to the world."

20 "If any merchant residing in our town or in its neighborhood does not want to join our guild and is attacked while on his way somewhere or his goods are stolen or he is challenged to a duel, he will receive no help from us."

21 "I free all those who have their guild, and belong to it, and who reside within the confines of its town from the toll at the port of Dixmude and at the port of Gravelines."

22 "Our burghers came together in a field next to the town within the village walls and, having called together the Flemings from all the places around us, they swore together on the relics of the saints"; "there was a great multitude of co-swearers who took the oath" (Galbert, 2013: 87).

23 "The citizens put off responding as to whether or not they would agree to welcome or elect the new count until they could summon the Flemings with whom they had established sacraments concerning the election, and together either agree to or reject the letter brought by the royal embassy. And [...] by common counsel [they] sent for the Flemings throughout the night so that they could agree to or reject the election that had been made of the person to be the new consul" (Galbert, 2013: 91).

24 "When the citizens had come together with the Flemings, they agreed by common counsel that"; "twenty knights and twelve of the older and wiser citizens" (Galbert, 2013: 91).

25 "Ysaac, however, hiding where he dared during the day and fleeing where he could during the night, reached the house of his sister, the wife of the aforementioned Guy of Steenvoorde, who led him to refuge in the abbey of Saint John of Thérouanne, which is situated on the hill overlooking the city. For since, driven by fear of God - or men - he wished to become a monk, he had asked some monk from Ename, who was supposed to give him a habit, to hide him there.

\section{His discovery, monastic profession, capture and death.}

Fyying rumor, however, reported that some of those who had killed the father of the fatherland, Charles, were hiding in the abbey of Saint John and this was immediately known throughout the town. Arnold, the son of the advocate Eustace, who wished himself to avenge the count's blood and had heard that the whole world was conspiring in this vengeance, therefore led his subordinates there towards nightfall and they watched the abbey all night so that no one who 
Jeff Rider, "Flanders was empty and uncultivated and heavily wooded"...

HSS, vol. VI, no. 2(2017): 13-34

was hiding there would be able to flee under the cover of darkness. Ysaac realized that this trap had been set there for him, however, fled trembling to the lord Abbot Folquin, and with humble and insistent entreaty finally got him to agree to give him the monk's habit which he so desired. Arnold nevertheless appeared at the abbey the next day with his men, and, when Ysaac had been led out and arrested him on his own confession, he immediately ordered him to be stripped of his monkish clothes and paraded to the city, naked and barefoot, with his hands tied behind his back."

26 "So as the king was fleeing [back to France], the count arrived the next morning and recovered the city, but grieved deeply over the injuries done to the churches and people." See Rider, 2015 for 2014: 24.

27 "Was always plotting the death of his lord"; "night came while the ships were gliding along the River Scheldt, and the castellan Boldran and his knight Erembald, in whom he trusted more than anyone else, and many others, dressed in full mail coats and prepared for battle, dropped anchor in the middle of the river in order to wait for daylight. [...] When the silence of the night had come, while the castellan was standing urinating at the edge of the ship, Erembald ran up from behind and cast down his lord, flung far from the ship, into the depths of the watery torrent. This was done while the others were sleeping and no one other than the adulterer knew what had become of the castellan" (Galbert, 2013: 124).

\section{Biographical note}

Jeff Rider is a professor of the literature and history of medieval Europe. He is the author, editor or translator of eleven books and has published over thirty articles, essays, or chapters in collective works. A graduate of Yale University in combined French and English literature, he received a Diplôme d'études médiévales from the Université Catholique de Louvain and a master's and doctorate in comparative literature from the University of Chicago. Rider has received multiple grants including grants from the National Endowment for the Humanities and the Royal Flemish Academy of Belgium for Science and the Arts. 